\title{
Oral propranolol as a new treatment for facial infantile hemangioma: case report
}

\author{
Propranolol oral: novo tratamento para hemangioma facial em bebês: relato de caso
}

\author{
Rosane da Cruz Ferreira ${ }^{1}$, Francisco Romeu Locatelli WolfF² ${ }^{2}$ Ricardo Mörschbächer ${ }^{3}$
}

\begin{abstract}
Hemangiomas are the most common benign tumors of infancy. Despite their selflimited course, infantile capillary hemangiomas can impair vital or sensory functions as vision and cause cosmetic deformity. The usual treatments include oral/intralesional steroids, al pha interferon, cytotoxins, pulsed dye laser and cosmetic surgery resection These treatments are not free of multiple complications and toxic side effects. This report describes the case of a 3-month-old female baby with progressively increasing hemangioma of the left upper eyelid impinging over the visual field. The hemangioma promptly responded to low-dose oral propranolol. A clinical response was noticed few days after the beginning of the treatment, with regression to $1 / 4$ of its original size in 45 days of treatment, and to less than $1 / 10$ after 8 months, free of any major side effects.
\end{abstract}

Keywords: Hemangioma; Hemangioma, capillary/therapy; Propranolol/therapeutic use; Case reports; Infant, newborn

\begin{abstract}
RESUMO
Hemangiomas são os tumores benignos mais comuns durante o primeiro ano de vida. Apesar do seu curso autolimitado, os hemangiomas capilares podem prejudicar funções vitais ou sensoriais como a visão e causar alteração estética. O tratamento usual inclui esteróides orais ou intralesionais, interferon alfa, citotoxinas, laser e ressecção cirúrgica. Entretanto estes tratamentos não estão livres de complicações e efeitos adversos. Este relato descreve o caso de um bebê feminino de 3 meses com um hemangioma rapidamente progressivo na pálpebra superior esquerda, causando obstrução no eixo visual. 0 hemangioma respondeu rapidamente a uma baixa dose oral de propranolol. A resposta clínica foi notada poucos dias após o início do tratamento, com regressão a 1/4 do seu tamanho original após 45 dias de tratamento, e a menos de 1/10 após 8 meses, sem ter apresentado nenhum efeito adverso.
\end{abstract}

Descritores: Hemangioma; Hemangioma capilar/terapia; Propranolol/uso terapêutico; Relato de casos; Recém-nascido

\section{INTRODUCTION}

Hemangiomas are the most common benign tumors of infancy. They are more common in white Caucasians, females (3:1) and premature babies (22\%). Capillary hemangioma generally is presented as a spot or well-defined purple lesion. The diagnosis of these tumors is based on physical examination. Its incidence is 1 to $3 \%$ in newborns. Infantile capillary hemangiomas are composed of a complex mixture of clonal endothelial cells associated with pericytes, dendritic cells, and mast cells ${ }^{(1-3)}$.

During the first year of life there is a proliferative phase, with increasing size of the lesion. After this period there is a slow spontaneous involution phase. Regulators of hemangioma growth and involution are poorly understood. During the growth phase, two major proangiogenic factors are involved: basic fibroblast growth factor (bFGF) and vascular endothelial growth factor (VEGF); histologic studies have shown that both endothelial and interstitial cells are actively dividing in this phase. During the involution phase, apoptosis has been shown ${ }^{(3)}$.

In up to $70 \%$ of the cases the tumor disappears completely until 7 years of age. Unfortunately, some hemangiomas may become large in size impinging on vital structures such as eyes, mouth, nose or larynx, and require certain therapeutic interventions to prevent major morbidities. Amblyopia is the most common complication of hemangioma of the eyelid. If not treated promptly, it may lead to irreversible visual loss in young children ${ }^{(1,4,5)}$.
Until today, oral or intralesional corticosteroids were the first line of treatment for severe infantile capillary hemangiomas. Other options include alpha interferon, vincristine, intralesional injection of sclerosing solutions, radiotherapy, as well as pulsed dye laser and cosmetic surgery resection ${ }^{(1,3,6-8)}$

We present a new and safe option for the treatment of severe facial capillary hemangiomas in infancy with a nonselective betablocker, low-dose oral propranolol.

\section{CASE REPORT}

A 3-month-old girl was examined for a progressively increasing hemangioma of the left upper eyelid. The lesion was a purplish tumor, impinging over the visual field and she could not open her left eye (Figure 1). She was born prematurely at 32 weeks and weighed $1800 \mathrm{~g}$. The ophthalmologic evaluation was normal. Treatment with propranolol, at an oral dose of $2 \mathrm{mg}$ per kilogram of body weight per day was initiated. The heart rate and blood pressure were closely monitored by the pediatrician and the baby never required hospitalization for any side effects.

One month and 15 days later, the child was able to open her eye spontaneously and the mass in the upper eyelid was considerably reduced in size. We were able to measure the visual acuity (with Teller acuity cards) and it was worse in the left eye. Occlusion therapy was started, 4 hs daily. After 3 months of amblyopia treatment,
Submitted for publication: March 4, 2010

Accepted for publication: July 23, 2010

Study carried out at VER Institute - Porto Alegre.

${ }^{1}$ Physician, Federal University of São Paulo - UNIFESP - São Paulo (SP) - Brazil.

Physician, Pediatrics Brazilian Society, Neonatal and Pediatrics ICU Coordinator, Passo Fundo Hospital and Pronto Clínica Hospital, Passo Fundo (RS), Brazil.

3 Physician, Oculoplastic Sector. Santa Casa de Misericórdia de Porto Alegre, Porto Alegre (RS), Physician,
Brazil.
Funding: No specific financial support was available for this study.

Disclosure of potential conflicts of interest: R.C.Ferreira, None; F.R.L.Wolff, None; R.Mörschbächer, None.

Correspondence address: Rosane C. Ferreira. Rua dos Andradas, 1.234/2.408 - Porto Alegre RS - 80020-008 - Brazil - E-mail: rosaneferreira@hotmail.com

Editorial Note: After completing the confidential analysis of the manuscript, ABO discloses, with her agreement, the name Dr. Flávia Augusta Attié de Castro as a reviewer. We thank her effort and expertise in participating in this process. 


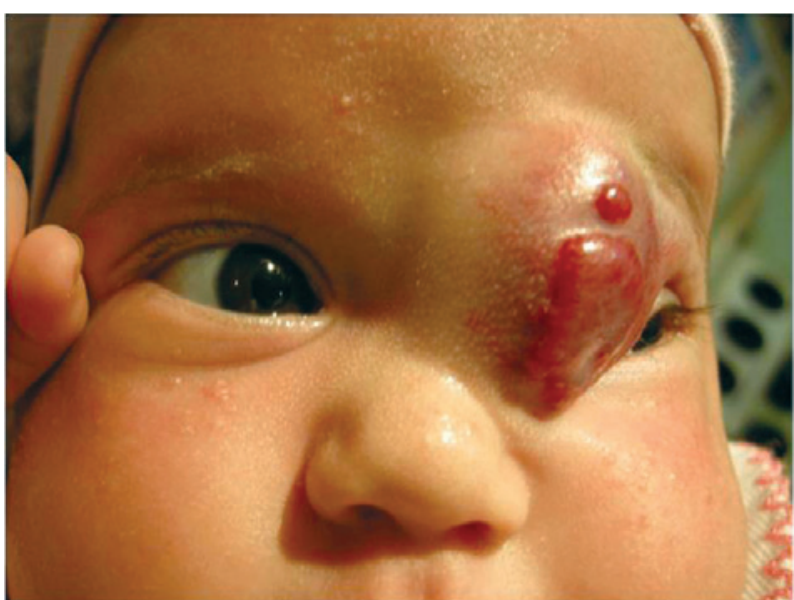

Figure 1. Hemangioma - before treatment.

the visual acuity was the same in both eyes and occlusion therapy was discontinued. After 5 months of treatment with oral propranolol (baby at the age of 8 months) the involution of the tumor slowed down and the dosage was slowly increased to $4 \mathrm{mg} / \mathrm{kg}$. After 8 months of treatment, the lesion was smaller than $1 / 10$ of its original size (Figure 2). The oral dosage of $4 \mathrm{mg} / \mathrm{kg}$ was maintained until the baby was one year old. Discontinuation of therapy through tapering of propranolol over a 3 month period was then performed

\section{DISCUSSION}

With the objective of getting better results and treating lesions with difficult surgical access, new therapeutic modalities have been developed. Until now, the best results were observed with steroids and interferon-alpha with a high percentage of side effects ${ }^{(3)}$.

The efficacy of propranolol in decreasing the size of hemangiomas was discovered by chance and published for the first time by some authors in $2008^{(3)}$. They published a case of a child with a nasal capillary hemangioma. Despite corticosteroid treatment, the lesion was stabilized but obstructive hypertrophic myocardiopathy developed, so the patient was treated with propranolol. The hemangioma changed from intense red to purple, and it softened. The corticosteroids were tapered, but the hemangioma continued to improve. When the corticosteroids were discontinued, no regrowth of the hemangioma was noted.

After this first report, other cases have been published ${ }^{(4,5)}$, the greatest series with 30 and 32 patients ${ }^{(4-9)}$.

Potential explanations for the therapeutic effect of propranolol a nonselective beta-blocker - on infantile capillary hemangiomas include vasoconstriction, which is immediately visible as a change in color, associated with a palpable softening of the hemangioma; decreased expression of VEGF and bFGF genes through the downregulation of the RAF-mitogen-activated protein kinase pathway (which explains the progressive improvement of the hemangioma); and the triggering of apoptosis of capillary endothelial cells ${ }^{(10)}$.

Side effects of beta-blockers are well known. Propranolol can cause transient hypoglycemia, bradycardia, and hypotension and may predispose patients to hypoglycemia. Bronchospasm is usually

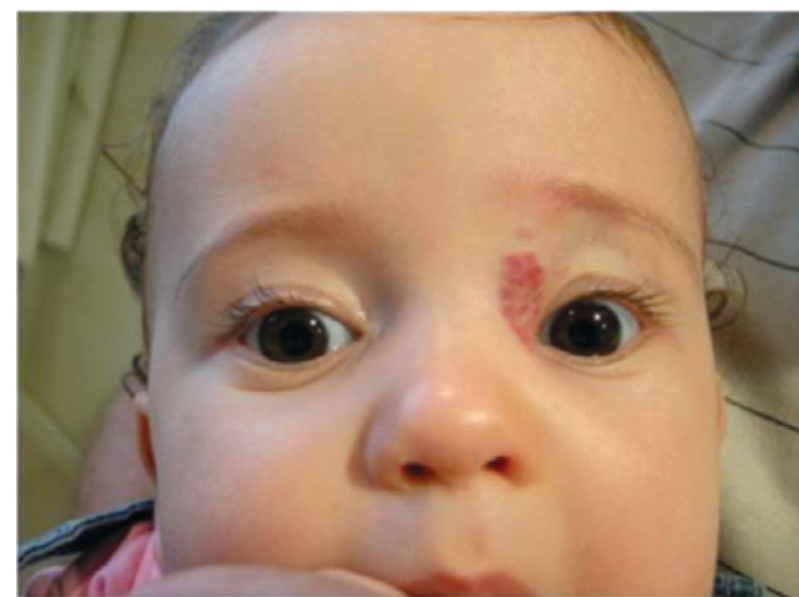

Figure 2. Hemangioma - 8 months after the beginning of the treatment.

seen as an exacerbation in patients with underlying reactive airways. These risks can be managed. Frequent pediatric follow-ups during therapy are important.

We did not follow any specific protocol for treatment, because at the time we treated this first baby there were no protocols. Some authors suggest a detailed protocol at their study ${ }^{(9)}$.

In this present case, oral propranolol was very successful in rapidly decreasing the size of the tumor and avoiding severe amblyopia, during the most important period of the visual development, with no side effects.

We add this Brazilian case to the few published by other colleagues and agree that propranolol is highly promising as an alternative pharmacologic agent, and may emerge as the preferred treatment for facial infantile hemangiomas.

\section{REFERENCES}

1. Junior NL, Cha SB, Cartum J, Rehder JR. Eficácia terapêutica do interferon alfa em criança com hemangioma gigante craniofacial: relato de caso. Arq Bras Oftalmol. 2008;71(3):423-6.

2. Frieden IJ, Haggstrom NA, Drolet BA, Mancini AJ. Friedlander SF. Boon L, et al. Infantile hemangiomas: current knowledge, future directions. Proceedings of a research workshop on infantile hemangiomas, April 7-9, 2005, Bethesda, Maryland, USA. Pediatr Dermatol. 2005;22(5):383-406.

3. Léauté-Labrèze C, Dumas de la Roque E, Hubiche T, Boralevi F, Thamo JB, Taieb A Propranolol for severe hemangiomas of infancy. N Engl J Med. 2008;358(24):2649-51. Comment in: N ENgl J Med. 2008;359(26):2846; author reply 2846-7. J R Coll Physicians Edinb. 2010;40(2):128-9

4. Buckmiller LM, Munson PD, Dyamenahalli U, Dai Y, Richter GT. Propranolol for infantile hemangiomas: early experience at a tertiary vascular anomalies center. Laryngoscope. 2010;120(4):676-81

5. Fay A, Nguyen J, Jakobiec FA, Meyer-Junghaenel L, Waner M. Propranolol for isolated orbital infantile hamangioma. Arch Ophthalmol. 2010;128(2):256-8.

6. O'Keefe M, Lanigan B, Byrne SA. Capillary hemangioma of the eyelids and orbit: a clinical review of the safety and efficacy of intralesional steroid. Acta Ophthalmol Scand. 2003; 81(3):294-8.

7. Kushner BJ. The treatment of periorbital infantile hemangioma with intralesional corticosteroid. Plast Reconstr Surg. 1985;76(4):517-26.

8. França VP, Soares EJ, Alvarenga DP. Hemangioma da infância, infiltração intralesional de triamcinolona: nossa experiência com 13 casos. Arq Bras Oftalmol. 1992;55(3):124-8.

9. Manunza F, Syed S, Laguda B, Linward J, Kennedy H, Gholam K, et al.. Propranolol for complicated infantile haemangiomas: a case series of 30 infants. Br J Dermatol. 2010; 162(2):466-8.

10. Sommers Smith SK, Smith DM. Beta blockade induces apoptosis in cultured capillary endothelial cells. In Vitro Cell Dev Biol Anim. 2002;38(5):298-304. 